\title{
Business Development Strategy in India for Overseas Construction Management Companies
}

\author{
Nirmalendu Bandyopadhyay* \\ Independent Consulting Engineer, India \\ *Corresponding author: Nirmalendu Bandyopadhyay, India \\ Submission: 睯September 18, 2017; Published: 眥 November 02, 2017
}

\section{Introduction}

India's is one of the fastest growing economies in the world and the last decade has shown that an average annual GDP growth has been around $9 \%$ and is achievable and sustainable due to steady growth in all the important sectors namely Services, Industry and Agriculture. The Industry sector has two major components namely production/Manufacturing and Infrastructures.

Contribution to the GDP comes from the Service sector to around $50 \%$, the industry $35 \%$ and the Agriculture $10 \%$. The rest comes from other sources. The Infrastructure sector accounts to $20 \%$ and includes mainly Roads, Ports, Airports, Real Estates, Special Economic Zones, Water Supply and Environment.

The country has entered into the $11^{\text {th }}$ Five Year Plan which has started in 2008 and to be over in 2012. The estimated Planned Expenditure by the Govt of India during this Plan period will be around Indian Rupees (INR) 34,385 Billions (=US \$8060 Billions).

In the Infrastructure sector alone the planned allotment is INR $20,271 \mathrm{Bn}$. The average construction costs under this heading comes to around $70 \%$ and the PM Consultancy services can be assumed at a moderate amount of $3 \%$ of the Construction costs. This is a very conservative assumption and is feasible. Thus the PM Consultancy can mop up around INR 426Bn during this plan period.

An overseas PM Consultant having adequately qualified and experienced Indian Manpower and backed up by overseas principal can expect to extract a substantial portion of this amount. To what extent this can be achieved, will depend on the BD Strategies and efficiency of operation. The PM Consultancy being a service oriented activity, a substantial part of the service sector investment can also be extracted through appropriate planning and activity orientation.

\section{BD Strategy}

It is essential to follow some procedures by an overseas company to start business in India. These are outlined in the attached document. Once the company is registered by the registrar of Companies, Govt of India, the next stage is to identify the most suitable location which will depend on the nature of business and the opportunities available nearby. For PM Consultancy, a few locations like Delhi, Bangalore, Pune, Chennai and Hyderabad are

good choices. If the company is targeting markets around India then a branch in Kolkata may be appropriate to cover Bangladesh, Thailand, Malaysia, Singapore and Indonesia. However, this can be decided later after a few years of operation when a large share of the Indian market is covered.

In these days of high competition, it may be worth to consider diversification in various areas of PM Consultancy rather than limiting to only Infrastructure projects. New technologies in areas of non conventional industries are coming to the market. It may be advantageous to enter in these sectors as well. It is necessary to have human resources as a blend of various specialization so that assorted type of work can be taken up. Creation of an appropriate team of professionals should be given topmost priority.

To start with, it may be advantageous to form joint ventures with established players or share their workloads to cover the running expenses. Once the business is established then there will be no dearth of orders. So, the initial strategy should be workload sharing with established players in the market and then become independent player once credibility is established. For this, the operating expenditures need to be limited. To do so, the company should look to retired but highly experienced professionals in the market. In India such people are plenty. The advantage is that there will be minimum overheads and salary bill will also be manageable. Some of the areas where beginning can be made include

a) Project Management Consultancy through preparation of project execution plans, QS and cost estimates, budgets, cash flow projections, continuous monitoring as the work progresses, generation of regular progress reports, highlighting areas of concerns and the steps necessary to correct them and project close out reports after completion.

b) Providing Health, Safety and Environment Management services.

c) Providing Quality Assurance and Quality Control services.

d) Providing Hazard studies to industrial plants.

e) Providing Human Factor Engineering services to industrial plants for higher efficiency. 
These services can be provided to both project owners and contractors and most of these activities can be done by retired professionals under contract agreement. The next stage is to enter into full fledged project management consultancy where the company will act as the clients' Project Manager from concept to project completion stage.

After establishing the Indian office, an introductory seminar can be held where senior executives from industries, government t officials and media persons can be invited to let everybody know the presence of the company and the areas where it provides services. This is to be followed up by regular visits to potential project owners.

\section{Manpower}

At the beginning, the overheads to be kept minimum therefore, regular employee should be limited to a few and most of the work to be executed through contract services as outlined earlier. Once the order flow starts and the company business looks up then full timers can be hired under planned programs.

\section{Economic Evaluation}

All figures are approx in Indian Rupees Lakhs, INR 100,000 $($ INR 1 Lakh = US\$2000 during 2011-12) (Figure 1)

\section{Capital Investment}

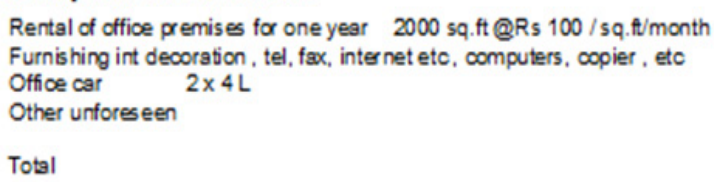

\section{Operating costs for one year}

$\begin{array}{llr}\text { Salaries ind overheads } & 4 \text { Sr Executives @ INR 2 L /pers on/month } & 96.0 \mathrm{~L} \\ & 6 \text { Staff members @INR } 50000 \mathrm{pp} / \mathrm{pm} & 36.0 \\ & 4 \text { Contract staff @ INR } 30000 \mathrm{pp} / \mathrm{pm} & 15.0 \\ & \text { 4 other staff @ INR } 10,000 \mathrm{pp} / \mathrm{pm} & 5.0\end{array}$

Other operating costs, tel, fax, inter net, car, security, entertainment eto

Total including $5 \%$ contingencies say

Operating cost will be projected to increase by $10 \%$ every year.

\section{Operating Incomes}

Available in the market INR $426 \mathrm{Bn}$ in 5 years =INR $85 \mathrm{Bn} / \mathrm{yr}$

Assuming $0.05 \%$ of this as the company's share, the annual turnover =

This can be assumed to reach this fioure in 2012 but less in the orevious vears

\section{INR Lakhs}

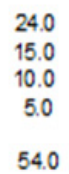

150.0

\section{Figure1}

Financial Summary (Figure in INR Lakhs)

(Table $1 \& 2$ )

Table 1:

\begin{tabular}{|c|c|c|c|c|c|c|c|c|c|c|}
\hline Year & 1 & 2 & 3 & 4 & 5 & 6 & 7 & 8 & 9 & 10 \\
\hline Income & 30 & 190 & 260 & 330 & 420 & 540 & 700 & 910 & 1180 & 1400 \\
\hline Expenditure & 200 & 220 & 240 & 270 & 300 & 330 & 360 & 400 & 440 & 490 \\
\hline Gross margin(-) & 170 & $(-) 30$ & 20 & 60 & 120 & 210 & 340 & 510 & 740 & 910 \\
\hline Tax @ $30 \%$ and 5 year tax Holiday for foreign & - & - & - & - & - & 60 & 100 & 150 & 220 & 280 \\
\hline
\end{tabular}

Table 2:

\begin{tabular}{|c|c|c|c|c|c|c|c|c|c|c|}
\hline Year & 1 & 2 & 3 & 4 & 5 & 6 & 7 & 8 & 9 & 10 \\
\hline Income & 30 & 190 & 260 & 330 & 420 & 540 & 700 & 910 & 1180 & 1400 \\
\hline Expenditure & 200 & 220 & 240 & 270 & 300 & 330 & 360 & 400 & 440 & 490 \\
\hline Gross margin(-) & 170 & $(-) 30$ & 20 & 60 & 120 & 210 & 340 & 510 & 740 & 910 \\
\hline Tax @ 30\% and 5 year tax Holiday for foreign & - & - & - & - & - & 60 & 100 & 150 & 220 & 280 \\
\hline Net margin & $(-) 170$ & $(-) 30$ & 240 & 270 & 300 & 150 & 240 & 360 & 520 & 630 \\
\hline Discount Cash Flow @ 20\% IRR & $(-) 70$ & $(-) 30$ & 139 & 130 & 120 & 53 & 65 & 82 & 99 & 101 \\
\hline Net Present Value @ 20\% IRR = INR 589Lakhs & & & & & & & & & & \\
\hline
\end{tabular}




\section{Conclusion and Observations}

The above analysis shows that the proposal to begin Indian operation will be highly attractive. Even if the current glut in the market is considered to last for another 5 years, the estimated Return on Investment will not be less than $15 \%$ with a payback period of 3 years. The first and second years may show negative results but from third year onwards, the situation will improve and from fourth year onwards the profitability will increase substantially. The 10 year financial analysis shows that even before the end of current $11^{\text {th }}$ Five year plan, the company will make up for its capital expenditures and will be solidly entrenched in this market.

The other advantage of early start up is that the market price is currently down in India in view of the worldwide meltdown. Therefore, it is an appropriate to start the operation as there is scope to bring down the Capital expenditure. It is therefore concluded that the proposal will be highly viable even with current market situation. Management will do well to decide fast and take appropriate actions. 